The effect of matured date palm tree (Phoenix dactylifera L.) fruit extract on miteinduced allergic symptoms in NC/Nga mice

Koji Karasawa ${ }^{1,2}$ and Hajime Otani ${ }^{1 *}$

${ }^{1}$ Interdisciplinary Graduate School of Science and Technology, Shinshu University, Minamiminowa-mura 8304, Kamiina-gun, Nagano 399-4598, Japan; ${ }^{2}$ Ina Food Industry Co., Ltd., Nishiharuchika 5074, Ina-shi, Nagano 399-4498, Japan

*Corresponding author: Hajime Otani, Ph.D.

Graduate School of Agriculture, Shinshu University, Minamiminowa-mura 8304, Kamiina-gun, Nagano 399-4598, Japan. E-mail address: otani84@shinshu-u.ac.jp 


\title{
The effect of matured date palm tree (Phoenix dactylifera L.) fruit extract on mite- induced allergic symptoms in NC/Nga mice
}

\begin{abstract}
The effect of a hot water extract of matured date palm tree fruit on allergic responses was investigated in $\mathrm{NC} / \mathrm{Nga}$ mice. The allergic score was significantly reduced in the mice fed a date palm tree fruit extract-added diet than the fruit extract-free diet. The levels of serum antigen-specific immunoglobulin $\mathrm{E}$ and spleen interleukin $-4^{+} \mathrm{CD} 4^{+}$cells were significantly lowered in the mice fed the fruit extract-added diet. Bruton's tyrosine kinase and IL-2-inducible T cell kinase mRNA expressions in spleen cells were significantly lowered in the mice fed the fruit extract-added diet. Moreover, chlorogenic acid and pelargonin decreased these mRNA expressions in $\mathrm{C} 3 \mathrm{H} / \mathrm{HeN}$ mouse spleen cell cultures. These results suggest that the date palm tree fruit extract may reduce allergic symptoms in mice via a decrease in the number of type 2 helper $T$ (Th2) cells, and a suppression of the expression of kinases involved in mast cell degranulation and $\mathrm{Th} 2$ cell differentiation.
\end{abstract}

Keywords: anti-allergic property; polyphenol; mast cell; Tec family kinase; NC/Nga mouse

\section{Introduction}

The number of patients diagnosed with allergic diseases such as atopic dermatitis, allergic asthma and allergic rhinitis has increased in many countries throughout the world. These type I allergic diseases are generally characterized by an elevation in serum immunoglobulin (Ig) E levels (Dreborg 2002). It is well established that interleukin (IL)-4, produced by type 2 helper $\mathrm{T}$ (Th2) cells, stimulates IgE production (Platts-Mills 2001). In contrast, type 1 helper T (Th1) cells mainly secrete interferon (IFN)- $\gamma$, which inhibits IL-4 production by Th2 cells (Pène et al. 1988). Therefore, the production of $\operatorname{IgE}$ is thought to be due to a skewed Th1/Th2 cell balance (Shirakawa et al. 1997; Hopkin 2002).

IgE potentially connects with high-affinity surface receptors (FceRI) on mast cells (Holowka et al. 2007). When an antigen binds to the IgE on mast cells, the IgE-FceRI complex leads to activation of Src, Syk and Tec family kinases, such as Bruton's 
tyrosine kinase (Btk) and IL-2-inducible T cell kinase (Itk) (Kawakami \& Galli 2002). These kinases result in a multimolecular signalosome complex that further activates multiple pathways, leading to mast cell degranulation, transcription factor activation and cytokine production (Rivera \& Gilfillan 2006; Felices et al. 2007). It may therefore be possible that allergic responses could be suppressed by a reduction in the expression of these kinases.

The authors recently observed that the ratio of Th1/Th2 cells in the spleen and Peyer's patch was higher in $\mathrm{C} 3 \mathrm{H} / \mathrm{HeN}$ mice fed a diet containing an extract of the matured date palm tree (Phoenix dactylifera L.) fruit than in mice fed a date palm tree fruit extract-free diet. We also found that polyphenols identified in the date palm tree fruit extract, such as chlorogenic acid and caffeic acid, increased the number of Th1 cells in $\mathrm{C} 3 \mathrm{H} / \mathrm{HeN}$ mouse Peyer's patch cell cultures (Karasawa et al. 2011). These results suggest that the date palm tree fruit extract might reduce type I allergic diseases via adjustment of the Th1/Th2 balance.

This study therefore evaluated the effect of an extract of the matured date palm tree fruit on allergic responses induced by a mite (Dermatophagoides farinae, $D f$ ) allergen in $\mathrm{NC} / \mathrm{Nga}$ mice. In addition, this study determined whether polyphenols present in the date palm tree fruit extract affect the expression of kinases involved in signal activation leading to degranulation and cytokine production in $\mathrm{C} 3 \mathrm{H} / \mathrm{HeN}$ mouse spleen cell cultures.

\section{Materials and methods}

\section{Materials}

Molecular/Por Ultrafiltration Membrane MWCO 500 was obtained from Spectrum Laboratories, Inc. (Rancho Dominguez, CA, USA). A defined protein-free purified diet (P5765) was purchased from Purina Mills (St. Louis, MO, USA). Phycoerythrin (PE)labeled anti-mouse IL-4 monoclonal antibody (mAb, clone 11B11), PE-labeled antimouse IFN- $\gamma$ mAb (clone XMG1.2), biotin-labeled anti-mouse CD4 mAb (clone RM4$5)$ and phycoerythrin/cyanine 5 ( $\mathrm{PE} / \mathrm{Cy} 5)$-labeled streptavidin were obtained from BioLegend (San Diego, CA, USA). Brefeldin A (BFA), ionomycin, streptomycin and phorbol 12-myristate 13-acetate (PMA) were purchased from Wako Pure Chemical Industries (Osaka, Japan). Df-extract, a mite allergen, was obtained from LSL (Tokyo, Japan). IntraPrep was purchased from Beckman Coulter (Marseille, France). Defined 
fetal bovine serum (FBS) was obtained from HyClone Laboratories (Logan, UT, USA). Penicillin was purchased from MP Biomedicals (Costa Mesa, CA, USA). Roswell Park Memorial Institute (RPMI)-1640 was purchased from Nissui Pharmaceutical (Tokyo, Japan). Horseradish peroxidase (HRP)-labeled anti-mouse IgE was obtained from Bethyl Laboratories (Montgomery, TX, USA). 3,3',5,5'-Tetramethyl benzidine (TMB) was purchased from KPL (Gaithersburg, MD, USA). Bovine serum albumin (BSA) was obtained from Sigma-Aldrich (St. Louis, MO, USA). Protocatechuic acid, chlorogenic acid, caffeic acid, pelargonin, and ferulic acid were obtained from Funakoshi Co., Ltd, (Tokyo, Japan) and syringic acid was purchased from Wako Pure Chemical Industries. All chemicals used in this study were of the highest analytical grade commercially available.

\section{Date palm tree fruit extract preparation}

Dried date palm tree fruit harvested in the United Arab Emirates (UAE) was obtained from Marubeni Corporation (Tokyo, Japan). The fruit (1,000 g), including peel and pulp but not seeds, was cut into pieces approximately $5 \times 5 \mathrm{~mm}$, and boiled in 9,000 $\mathrm{ml}$ of hot distilled water for $2 \mathrm{~h}$ under reflux. The supernatant was collected by centrifugation $(5,000 \times g, 30 \mathrm{~min})$ and ultrafiltrated using a Stirred Ultrafiltration Unit (Model UHP-150K; Advantec Toyo Kaisha, Ltd., Tokyo, Japan) with a Molecular/Por Ultrafiltration Membrane MWCO 500 to eliminate fructose and sucrose in the extract. The residue on the membrane was then dissolved in $500 \mathrm{ml}$ of distilled water, freezedried and used as the date palm tree fruit extract. The weight of date palm tree fruit extract obtained from $1,000 \mathrm{~g}$ fruit was $70 \mathrm{~g}$. The total content of polyphenols in the extract was $32.07 \mathrm{mg}$ of ferulic acid equivalents (FAE)/g. Hence, it was calculated that $1 \mathrm{~g}$ of the date palm tree fruit contained $2.24 \mathrm{mg}$ of FAE of polyphenols. Al-Farsi et al. (2005) reported that the content of polyphenols in the date palm tree fruit was 2.17 to $3.43 \mathrm{mg}$ of FAE/g. The polyphenol content of date palm tree fruit used in this study was within the amount of their report. On the other hand, we estimated that the content of protocatechuic acid, chlorogenic acid, caffeic acid, syringic acid, pelargonin and ferulic acid identified in the previous study (Karasawa et al. 2011) was 10.78, 0.88, 0.74, 7.55, 3.64 and $3.15 \mathrm{mg} / \mathrm{g}$ date palm tree fruit extract, respectively, by ultra performance liquid chromatography analysis.

\section{Feeding procedure}


Five-week-old male NC/Nga mice were obtained from Charles River Japan (Kanagawa, Japan). The mice were first assigned to different test regimens as shown in Figure 1. The mice were fed a commercial mouse powder feed (Oriental Yeast Co., Tokyo, Japan) for 1 week, and subsequently fed P5765 supplemented with 25\% OVA (date palm tree fruit extract-free (date palm-free) diet, $n=4$ ) or both $24 \%$ OVA and 1\% date palm tree fruit extract (date palm tree fruit extract-added diet, $n=5$ ) between 6 and 21 weeks of age. The detailed composition of each diet is shown in Figure 1. The mice were intradermally injected with $5 \mu \mathrm{g}$ of Df-extract dissolved in $10 \mu \mathrm{l}$ of saline solution into the ventral side of their right ear weekly from 6 to 21 weeks of age. Ear thickness was measured weekly prior to the first injection and $24 \mathrm{~h}$ after each intradermal injection. Food and water were supplied ad libitum throughout the course of the experiment. The mice were housed at $23 \pm 2{ }^{\circ} \mathrm{C}$ under a standard 12-h light-dark cycle. Blood and spleen samples were collected immediately following a lethal dose of ether at 21 weeks of age. Serum was obtained by centrifugation at $450 \times g$ for $60 \mathrm{~min}$ at $4^{\circ} \mathrm{C}$ and was stored at $-30^{\circ} \mathrm{C}$ until use. All animal experimentation undertaken during this study was conducted in accordance with the guidelines for the Regulation of Animal Experimentation at Shinshu University, and according to Law no. 105 and Notification no. 6 of the Japanese government.

\section{Allergic Score}

Allergic symptoms were scored in accordance with the description of Matsuda et al. (1997). The degree of erythema, hemorrhaging, edema, scab/excoriation, and scaling/dryness was scored from 0 points (none) to 2 points (severe). Scoring was conducted weekly and at random by 2 scorers. The sum of these scores was defined as the allergic score.

\section{Spleen cell suspensions and cell cultures}

Spleen cell suspensions were prepared as described previously (Tobita et al. 2009). Aliquots $(1,000 \mu \mathrm{l})$ of the cell suspensions were plated into the wells of a 24 -well flat bottom plate (Sarstedt, Inc., Newton, NC, USA). Individual standard polyphenols were dissolved in dimethyl sulfoxide (DMSO) and added into the medium at a final concentration of $4 \mathrm{nmol} / \mathrm{ml}$. The final concentration of DMSO was $0.01 \%$, which has been determined to be noncytotoxic. The cells were cultured at $37{ }^{\circ} \mathrm{C}$ in a humidified $5 \% \mathrm{CO}_{2}$ incubator for $24 \mathrm{~h}$, and used for analysis of mRNA expression. 


\section{Cell function analysis}

Cell surface markers and intracellular cytokines were labeled according to a previously described procedure (Tobita et al. 2009). Cell numbers were determined using a Guava personal cell function analyzer (Guava PCA, Guava Technologies, Hayward, CA, USA).

\section{Antibody analysis}

Serum total and Df-specific IgE levels were measured by enzyme-linked immunosorbent assay (ELISA) according to a previously described procedure (Tobita et al. 2009).

\section{Preparation of total RNA and real-time reverse transcription (RT)-polymerase chain reaction (PCR)}

Total RNA from spleen cells was extracted and real-time RT-PCR was performed according to a previously described procedure (Tobita et al. 2009). The primer sequence for Btk and Itk amplification was reported by Lucas et al. (2007), and that for glyceraldehyde-3-phosphate dehydrogenase (GAPDH) was reported previously (Tobita et al. 2006). The relative amount of each mRNA was normalized using GAPDH expression as an internal control. An expression index was calculated from the normalized relative amount in the absence of polyphenol to the normalized relative amount in the presence of polyphenol. This analysis was carried out in at least triplicate, and representative results are presented.

\section{Statistical analysis}

Data are presented as the means \pm standard deviation (SD). Statistical analyses were performed using Dunnett's multiple comparison tests for one-way analysis of variance or Student's $t$-test. Differences were considered significant when $P$-values were less than 0.05 .

\section{Results}

Effects of a date palm tree fruit extract-added diet on allergic symptoms 
Six-week-old NC/Nga mice were fed either a date palm tree fruit extract-added diet or a date palm-free diet for 15 weeks. No significant differences in body weight were observed between the mice fed these diets (data not shown).

Figure 2 presents ear thickness and allergic score of the mice. Ear thickness was significantly reduced in mice fed the date palm tree fruit extract-added diet than in mice fed the date palm-free diet between 11 and 21 weeks of age. The relative ear thickness in mice fed the date palm tree fruit extract-added diet at 21 weeks of age was approximately $40 \%$ of that observed in mice fed the date palm-free diet at the same age. Similarly, allergic score was significantly decreased in the mice fed the date palm tree fruit extract-added diet at 14 and between 18 and 21 weeks of age. The relative allergic score in the mice fed the date palm tree fruit extract-added diet at 21 weeks of age was less than $60 \%$ of that observed in mice fed the date palm-free diet.

\section{Effects of a date palm tree fruit extract-added diet on total and Df-specific IgE levels in mouse serum}

Figure 3 shows the serum level of total and Df-specific IgE in the 21-week-old mice. Both the total and Df-specific IgE levels were significantly lower in mice fed the date palm tree fruit extract-added diet than in mice fed the date palm-free diet.

\section{Effects of a date palm tree fruit extract-added diet on the number of immunocompetent cells in mouse spleen}

Figure 4 presents the number of spleen IFN- $\gamma^{+} \mathrm{CD} 4^{+}$cells, IL- $4^{+} \mathrm{CD} 4^{+}$cells and the ratio of IFN- $\gamma^{+} \mathrm{CD} 4^{+} / \mathrm{IL}-4^{+} \mathrm{CD} 4^{+}$cells in the 21 -week-old mice. The number of IFN$\gamma^{+} \mathrm{CD} 4^{+}$cells was significantly increased, whereas the number of $\mathrm{IL}-4^{+} \mathrm{CD} 4^{+}$cells was significantly decreased in mice fed the date palm tree fruit extract-added diet than in mice fed the date palm-free diet. The ratio of IFN $-\gamma^{+} \mathrm{CD} 4^{+} / \mathrm{IL}-4^{+} \mathrm{CD} 4^{+}$cells was higher in the mice fed the date palm tree fruit extract-added diet than in the mice fed the date palm-free diet.

\section{Effects of a date palm tree fruit extract-added diet on Btk and Itk mRNA expressions in mouse spleen cells}

Figure 5 shows the expression levels of Btk and Itk mRNA in the spleen of 21-weekold mice. The expression level of both mRNAs was significantly lower in mice fed the date palm tree fruit extract-added diet than in mice fed the date palm-free diet. 


\section{Effects of polyphenols present in the date palm tree fruit on Btk and Itk mRNA expression in mouse spleen cell cultures}

Table 1 presents the effect of six polyphenols, previously identified in the date palm Table 1 tree fruit extract (Karasawa et al. 2011), on Btk and Itk mRNA expression levels in $\mathrm{C} 3 \mathrm{H} / \mathrm{HeN}$ mouse spleen cell cultures. Pelargonin significantly decreased Btk mRNA expression compared to polyphenol-free, protocatechuic acid, chlorogenic acid, caffeic acid, syringic acid and ferulic acid. Chlorogenic acid and pelargonin significantly reduced Itk mRNA expression compared to polyphenol-free, protocatechuic acid, caffeic acid, syringic acid and ferulic acid.

\section{Discussion}

Date palm tree fruit has been harvested in North Africa for at least 3,500 years (Copley et al. 2001), and its cultivation has now spread to the Middle East, parts of Central and South America, and Southern Europe (Hong et al. 2006; Rock et al. 2009). Date palm tree fruit is commonly consumed in the Middle East not only as fresh fruit, but also dried, and has been considered a medicinal food because of its antimicrobial capacity (Sallal \& Ashkenani 1989; Shraideh et al. 1998). We recently demonstrated that a date palm tree fruit extract potently enhanced the ratio of $\mathrm{Th} 1 / \mathrm{Th} 2$ cells in the spleen and Peyer's patch of C3H/HeN mice (Karasawa et al. 2011).

$\mathrm{NC} / \mathrm{Nga}$ mice are known to develop allergic dermatitis by intradermal injection of mite allergen without adjuvants (Sasakawa et al. 2001). In addition, Matsumoto et al. (1999) observed that the serum amount of total IgE in NC/Nga mice not developed dermatitis was less than $0.1 \mu \mathrm{g} / \mathrm{ml}$, while that of total $\operatorname{IgE}$ in the mice developed dermatitis was approximately $1 \mu \mathrm{g} / \mathrm{ml}$ or more. Hence, in the present study, we treated NC/Nga mice with Df according to the procedure described by Sasakawa et al. (2001). The serum total $\mathrm{IgE}$ amount in the $\mathrm{NC} / \mathrm{Nga}$ mice given the date palm-free diet was $13.59 \pm 1.08 \mu \mathrm{g} / \mathrm{ml}$ (Figure 3). These facts indicate that the mice could be induced allergic reactions appropriately.

Ear thickness and allergic score were significantly reduced in mice fed the date palm tree fruit extract-added diet than in mice fed the date palm-free diet (Figure 2). Additionally, the serum level of Df-specific IgE in the mice fed the date palm tree fruit extract-added diet was significantly lowered (Figure 3). These results indicate that 
feeding of mice with the date palm tree fruit extract-added diet reduces atopic dermatitis-like allergic symptoms via a reduction of Df-specific IgE production.

It is well established that $\mathrm{CD}^{+}$cells expressed a positive reaction for IL-4 and IL-5, but little reaction for IFN- $\gamma$ in the spleens of dermatitis developed NC/Nga mice (Matsumoto et al. 1999). In the present study, the number of spleen IFN- $\gamma^{+} \mathrm{CD} 4^{+}$(Th1) cells was significantly higher, while the number of spleen IL- $4^{+} \mathrm{CD} 4^{+}(\mathrm{Th} 2)$ cells was significantly lower in $\mathrm{NC} / \mathrm{Nga}$ mice fed the date palm tree fruit extract-added diet than in the mice fed the date palm-free diet (Figure 4). These results meant that the date palm tree fruit extract might shift to a Th1 dominant state in Th1/Th2 balance in the mice. It is well known that Th1 dominant state decreases IgE production (Shirakawa et al. 1997; Hopkin 2002). These facts indicate that the decrease in the serum Df-specific IgE of mice fed the date palm tree fruit extract-added diet might be due to an improvement of the Th1/Th2 balance.

Tec family kinases, such as Btk and Itk, play essential roles in allergy associated cells (Kawakami \& Galli 2002; Ellmeier et al. 2011). Btk regulates early-phase effector function, such as degranulation and production of lipid mediators, and late-phase effector function, such as cytokine production (Ellmeier et al. 2011). Itk is a negative regulator of cytokine production in mast cells (Ellmeier et al. 2011) and T cells (Fowell et al. 1999). In particular, Itk is required for IL-4 secretion and Th2 differentiation in T cells (Fowell et al. 1999; Schaeffer et al. 2001). In the present study, Btk and Itk mRNA expressions were significantly lower in $\mathrm{NC} / \mathrm{Nga}$ mice fed the date palm tree fruit extract-added diet than in the mice fed the date palm-free diet (Figure 5). In addition, we investigated the effect of polyphenols previously identified in the date palm tree fruit extract (Karasawa et al. 2011) on these mRNA expressions in the spleen cell culture test. We used the spleen cells isolated from naïve $\mathrm{C} 3 \mathrm{H} / \mathrm{HeN}$ mice but not those from $\mathrm{NC} / \mathrm{Nga}$ mice, because NC/Nga mice might have already developed allergic reactions and the cells from these mice might not be affected by polyphenols in the cell cultures. Pelargonin reduced Btk mRNA expression, whereas chlorogenic acid and pelargonin decreased Itk mRNA expression in $\mathrm{C} 3 \mathrm{H} / \mathrm{HeN}$ mouse spleen cell cultures (Table 1). This is the first report that polyphenols, such as chlorogenic acid and/or pelargonin, reduced the expression of Tec family kinases involved in FceRI-IgE mediated signal activation leading to degranulation in mast cells and Th2 differentiation.

In the present study, the concentration of chlorogenic acid and pelargonin in the cell cultures, that reduced Btk and Itk mRNA expression, was $4 \mathrm{nmol} / \mathrm{ml}$, i.e. chlorogenic 
acid; $1.42 \mu \mathrm{g} / \mathrm{ml}$ and pelargonin; $2.52 \mu \mathrm{g} / \mathrm{ml}$. On the other hand, the average intake of the date palm tree fruit extract-added diet in the breeding test was approximately 2.86 $\mathrm{g} /$ day/mouse (data not shown). The ratio of the date palm tree fruit extract in the diet was $1 \%$ (Table 1). In addition, the amount of chlorogenic acid and pelargonin in the date palm tree fruit extract was 0.88 and $3.64 \mathrm{mg}$ of FAE/g, respectively, as mentioned in "Materials and Methods" section. Thus, it is estimated that the average intake of chlorogenic acid and pelargonin was 25.2 and $104.1 \mu \mathrm{g} /$ day/mouse, respectively. These facts suggest that chlorogenic acid and pelargonin might be associable with the reduction of Btk and Itk mRNA expression in the mice given the date palm tree fruit extract-added diet.

In conclusion, we propose that the date palm tree fruit, particularly the presence of certain polyphenols, appears to reduce allergic responses via a reduction in the number of Th2 cells, and a suppression of the expression of kinases involved in mast cell degranulation and Th2 cell differentiation.

\section{References}

Al-Farsi M, Alasalvar C, Morris A, Baron M, \& Shahidi F. (2005). Comparison of antioxidant activity, anthocyanins, carotenoids, and phenolics of three native fresh and sun-dried date (Phoenix dactylifera L.) varieties grown in Oman. Journal of Agricultural and Food Chemistry, 53, 7592-7599.

Copley, M.S., Rose, P.J., Clampham, A., Edwards, D.N., Horton, M.C., \& Evershed, R.P. (2001). Detection of palm fruit lipids in archaeological pottery from Oasr Ibrim, Egyptian Nubia. Proceedings. Biological Sciences, 268, 593-597.

Dreborg, S. (2002). The implications of nomenclature. Annals of Allergy, Asthma, and Immunology, 89, 83-85.

Ellmeier, W., Abramova, A., \& Schebesta, A. (2011). Tec family kinases: regulation of FceRI-mediated mast-cell activation. FEBS Journal, 278, 1990-2000.

Felices, M., Falk, M., Kosaka, Y., \& Berg, L.J. (2007). Tec kinases in T cell and mast cell signaling. Advances in Immunology, 93, 145-184.

Fowell, D.J., Shinkai, K., Liao, X.C., Beebe, A.M., Coffman, R.L., Littman, D.R., \& Locksley, R.M. (1999). Impaired NFATc translocation and failure of Th2 development in Itk-deficient $\mathrm{CD}^{+} \mathrm{T}$ cells. Immunity, 11, 399-409. 
Holowka, D., Sil, D., Torigoe, C., \& Baird, B. (2007). Insights into immunoglobulin E receptor signaling from structurally defined ligands. Immunological Reviews, 217, 269-279.

Hong, Y.J., Tomas-Barberan, F.A., Kader, A.A., \& Mitchell, A.E. (2006). The flavonoid glycosides and procyanidin composition of Deglet Noor dates (Phoenix dactylifera). Journal of Agricultural and Food Chemistry, 54, 2405-2411.

Hopkin, J.M. (2002). The rise of atopy and links to infection. Allergy, 57, 5-9.

Karasawa, K., Uzuhashi, Y., Hirota, M., \& Otani, H. (2011). A matured fruit extract of date palm tree (Phoenix dactylifera L.) stimulates the cellular immune system in mice. Journal of Agricultural and Food Chemistry, 59, 11287-11293.

Kawakami, T., \& Galli, S.J. (2002). Regulation of mast-cell and basophil function and survival by IgE. Nature Reviews. Immunology, 2, 773-786.

Matsuda, H., Watanabe, N., Geba, G.P., Sperl, J., Tsudzuki, M., Hiroi, J., Matsumoto, M., Ushio, H., Saito, S., Askenase, P.W., \& Ra, C. (1997). Development of atopic dermatitis-like skin lesion with IgE hyperproduction in $\mathrm{NC}$ Nga mice. International Immunology, 9, 461-466.

Matsumoto, M., Ra, C., Kawamoto, K., Sato, H., Itakura, A., Sawada, J., Ushio, H., Suto, H., Mitsuishi, K., Hikasa, Y., \& Matsuda, H. (1999). IgE hyperproduction through enhanced tyrosine phosphorylation of Janus kinase 3 in NC/Nga mice, a model for human atopic dermatitis. The Journal of Immunology, 162, 1056-1063.

Lucas, J.A., Felices, M., Evans, J.W., \& Berg, L.J. (2007). Subtle defects in pre-TCR signaling in the absence of the Tec kinase Itk. The Journal of Immunology, 179, 7561-7567.

Pène, J., Rousset, F., Brière, F., Chrétien, I., Paliard, X., Banchereau, J., Spits, H., \& De Vries, J.E. (1988). IgE production by normal human B cells induced by alloreactive $\mathrm{T}$ cell clones is mediated by IL-4 and suppressed by IFN- $\gamma$. The Journal of Immunology, 141, 1218-1224.

Platts-Mills, T.A. (2001). The role of immunoglobulin $\mathrm{E}$ in allergy and asthma. American Journal of Respiratory and Critical Care Medicine, 164, 1-5.

Rivera, J., \& Gilfillan, A.M. (2006). Molecular regulation of mast cell activation. The Journal of Allergy and Clinical Immunology, 117, 1214-1225.

Rock, W., Rosenblat, M., Borochov-Neori, H., Volkova, N., Judeinstein, S., Elias, M., \& Aviram, M. (2009). Effects of date (Phoenix dactylifera L., Medjool or Hallawi Variety) consumption by healthy subjects on serum glucose and lipid levels and on 
serum oxidative status: a pilot study. Journal of Agricultural and Food Chemistry, 57, 8010-8017.

Sallal, A-K.J., \& Ashkenani, A. (1989). Effect of date extract on growth and spore germination of Bacillus subtilis. Microbios, 59, 203-210.

Sasakawa T, Higashi Y, Sakuma S, Hirayama Y, Sasakawa Y, Ohkubo Y, Goto T, Matsumoto M, \& Matsuda H. (2001). Atopic dermatitis-like skin lesions induced by topical application of mite antigens in NC/Nga mice. International Archives of Allergy and Immunology, 126, 239-247.

Schaeffer, E.M., Yap, G.S., Lewis, C.M., Czar, M.J., McVicar, D.W., Cheever, A.W., Sher, A., \& Schwartzberg, P.L. (2001). Mutation of Tec family kinases alters T helper cell differentiation. Nature Immunology, 2, 1183-1188.

Shirakawa, T., Enomoto, T., Shimazu, S., \& Hopkin, J.M. (1997). The inverse association between tuberculin responses and atopic disorder. Science, 275, 77-79.

Shraideh, Z.A., Abu-Elteen, K.H., \& Sallal, A-K.J. (1998). Ultrastructural effects of date extract on Candida albicans. Mycopathologia, 142, 119-123.

Tobita, K., Kawahara, T., \& Otani, H. (2006). Bovine $\beta$-casein (1-28), a casein phosphopeptide, enhances proliferation and IL-6 expression of mouse CD19+ cells via Toll-like receptor 4. Journal of Agricultural and Food Chemistry, 54, 8013-8017.

Tobita, K., Yanaka, H., \& Otani, H. (2009). Heat-treated Lactobacillus crispatus KT strains reduce allergic symptoms in mice. Journal of Agricultural and Food Chemistry, 57, 5586-5590. 


\section{Figure legends}

Figure 1. Experimental schedules and composition of diets. After pre-breeding for 1 week, NC/Nga mice were fed the date palm-free or date palm tree fruit extract-added diet. The mice were intradermally injected with $5 \mu \mathrm{g}$ of Df-extract dissolved in $10 \mu \mathrm{l}$ of saline solution into the ventral side of the right ear weekly between 6 and 21 weeks of age.

Figure 2. Ear thickness and allergic score in NC/Nga mice fed the date palm-free (the blank circle) or date palm tree fruit extract-added (the filled circle) diet. Ear thickness and allergic score were assessed weekly. Data are presented as the mean $\pm \operatorname{SD}(n=4$ for date palm-free diet and $n=5$ for date palm tree fruit extract-added diet). ${ }^{*} P<0.05$.

Figure 3. Serum levels of total and Df-specific IgE in NC/Nga mice fed the date palmfree (the blank column) or date palm tree fruit extract-added (the filled column) diet. Data are presented as the mean $\pm \operatorname{SD}(n=4$ for date palm-free diet and $n=5$ for date palm tree fruit extract-added diet). $* P<0.05$.

Figure 4. Numbers of spleen IFN $-\gamma^{+} \mathrm{CD} 4^{+}$and IL- $4^{+} \mathrm{CD} 4^{+}$cells in $\mathrm{NC} / \mathrm{Nga}$ mice fed the date palm-free (the blank column) or date palm tree fruit extract-added (the filled column) diet. Data are presented as the mean \pm SD $(n=4$ for date palm-free diet and $n$ $=5$ for date palm tree fruit extract-added diet). ${ }^{*} P<0.05$.

Figure 5. Relative Btk and Itk mRNA expression in spleen cells of NC/Nga mice fed the date palm-free (the blank column) or date palm tree fruit extract-added (the filled column) diet. Data are presented as the mean $\pm \operatorname{SD}(n=4$ for date palm-free diet and $n$ $=5$ for date palm tree fruit extract-added diet). $* P<0.05$. 


\section{TABLE}

Table 1. Relative mRNA expression in $\mathrm{C} 3 \mathrm{H} / \mathrm{HeN}$ mouse spleen cells cultured with 6 kinds of polyphenols identified in the date palm tree fruit extract.

\begin{tabular}{lccccccc}
\hline & \multicolumn{5}{c}{ Relative expression } \\
\cline { 2 - 7 } Gene & Free (control) & $\begin{array}{c}\text { Protocatechuic } \\
\text { acid }\end{array}$ & $\begin{array}{c}\text { Chlorogenic } \\
\text { acid }\end{array}$ & Caffeic acid & Syringic acid & Pelargonin & Ferulic acid \\
\hline Btk & $1.00 \pm 0.22^{a}$ & $0.92 \pm 0.17^{a}$ & $0.68 \pm 0.05^{a}$ & $0.82 \pm 0.12^{a}$ & $0.76 \pm 0.06^{a}$ & $0.52 \pm 0.09^{b}$ & $0.73 \pm 0.10^{a}$ \\
Itk & $1.00 \pm 0.15^{a}$ & $1.02 \pm 0.17^{a}$ & $0.59 \pm 0.09^{b}$ & $1.00 \pm 0.15^{a}$ & $0.89 \pm 0.14^{a}$ & $0.58 \pm 0.11^{b}$ & $0.85 \pm 0.11^{a}$ \\
\hline
\end{tabular}

Spleens were obtained from male $\mathrm{C} 3 \mathrm{H} / \mathrm{HeN}$ mice at six weeks of age bred with a commercial mouse powder diet.

Data are presented as the mean $\pm \mathrm{SD}(n=3)$

Items indicated with different letters (i.e. $a, b)$ are significantly different $(P<0.05)$.

Table 1. Karasawa \& Otani 


\section{FIGURES}

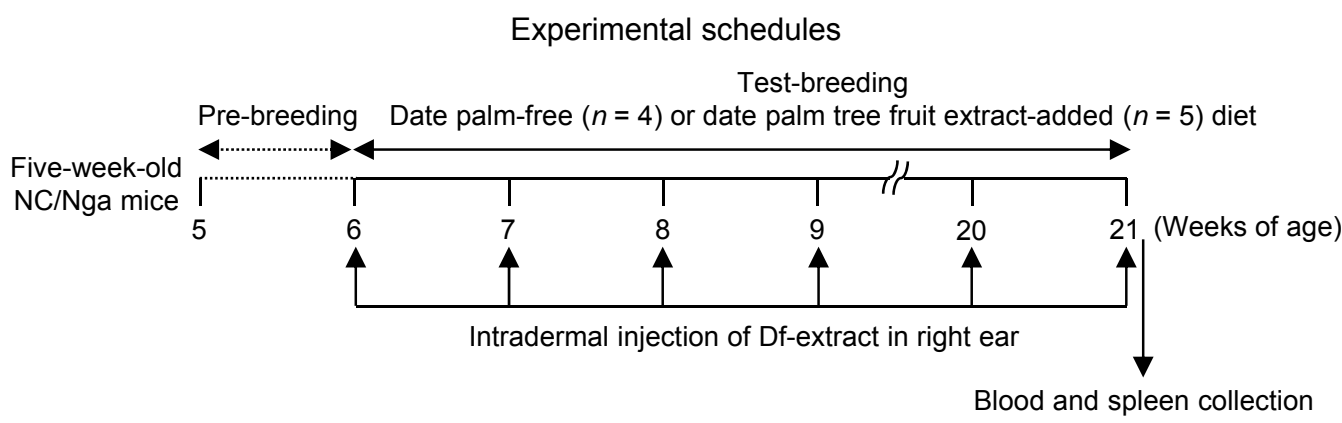

\begin{tabular}{|c|c|c|}
\hline \multirow[b]{2}{*}{ Component } & Date palm-free diet & $\begin{array}{l}\text { Date palm tree fruit } \\
\text { extract-added diet }\end{array}$ \\
\hline & \multicolumn{2}{|c|}{$\%$} \\
\hline Date palm tree fruit extract & 0.000 & 1.000 \\
\hline Ovalbumin & 25.000 & 24.000 \\
\hline Dextrin & 32.738 & 32.738 \\
\hline Sucrose & 27.112 & 27.112 \\
\hline $\mathrm{RP}$ mineral mix \#10 & 3.750 & 3.750 \\
\hline Corn oil & 3.750 & 3.750 \\
\hline Lard & 3.750 & 3.750 \\
\hline Powdered cellulose & 2.250 & 2.250 \\
\hline $\mathrm{RP}$ vitamin $\mathrm{mix}^{\mathrm{b}}$ & 1.500 & 1.500 \\
\hline Choline chloride & 0.150 & 0.150 \\
\hline$\overline{\text { Total }}$ & 100.000 & 100.000 \\
\hline
\end{tabular}

a RP mineral mix \#10: calcium, $0.6 \%$; phosphorus, $0.4 \%$; potassium, $0.4 \%$; magnesium, 0.07\%; sodium, 0.21\%; chlorine, $0.24 \%$; fluorine, $5.0 \mathrm{ppm}$; iron, 60 ppm; zinc, 21 ppm; manganese, 65 ppm; copper, 15.0 ppm; cobalt, $3.2 \mathrm{ppm}$; iodine, $0.57 \mathrm{ppm}$; chromium, $3.0 \mathrm{ppm}$; molybdenum, $0.82 \mathrm{ppm}$; selenium, $0.23 \mathrm{ppm}$

b RP vitamin mix: vitamin K, 10.4 ppm; thiamin hydrochloride, $20.6 \mathrm{ppm}$; riboflavin, $20.0 \mathrm{ppm}$; niacin, $90 \mathrm{ppm}$; pantothenic acid, $55 \mathrm{ppm}$; choline chloride, $1400 \mathrm{ppm}$; folic acid, $4.0 \mathrm{ppm}$; pyridoxine,16.5 ppm; biotin, 0.4 $\mathrm{ppm}$; vitamin B12, $20 \mathrm{mcg} / \mathrm{kg}$; vitamin A, $22.1 \mathrm{IU} / \mathrm{g}$; vitamin D3, $2.2 \mathrm{IU} / \mathrm{g}$; vitamin $\mathrm{E}, 50 \mathrm{IU} / \mathrm{kg}$; ascorbic acid, $0.0 \mathrm{ppm}$.

Figure 1. Experimental schedules and composition of diets. After pre-breeding for 1 week, $\mathrm{NC} / \mathrm{Nga}$ mice were fed the date palm-free or date palm tree fruit extractadded diet. The mice were intradermally injected with $5 \mu \mathrm{g}$ of Df-extract dissolved in $10 \mu \mathrm{l}$ of saline solution into the ventral side of the right ear weekly between 6 and 21 weeks of age.

Figure 1. Karasawa \& Otani 

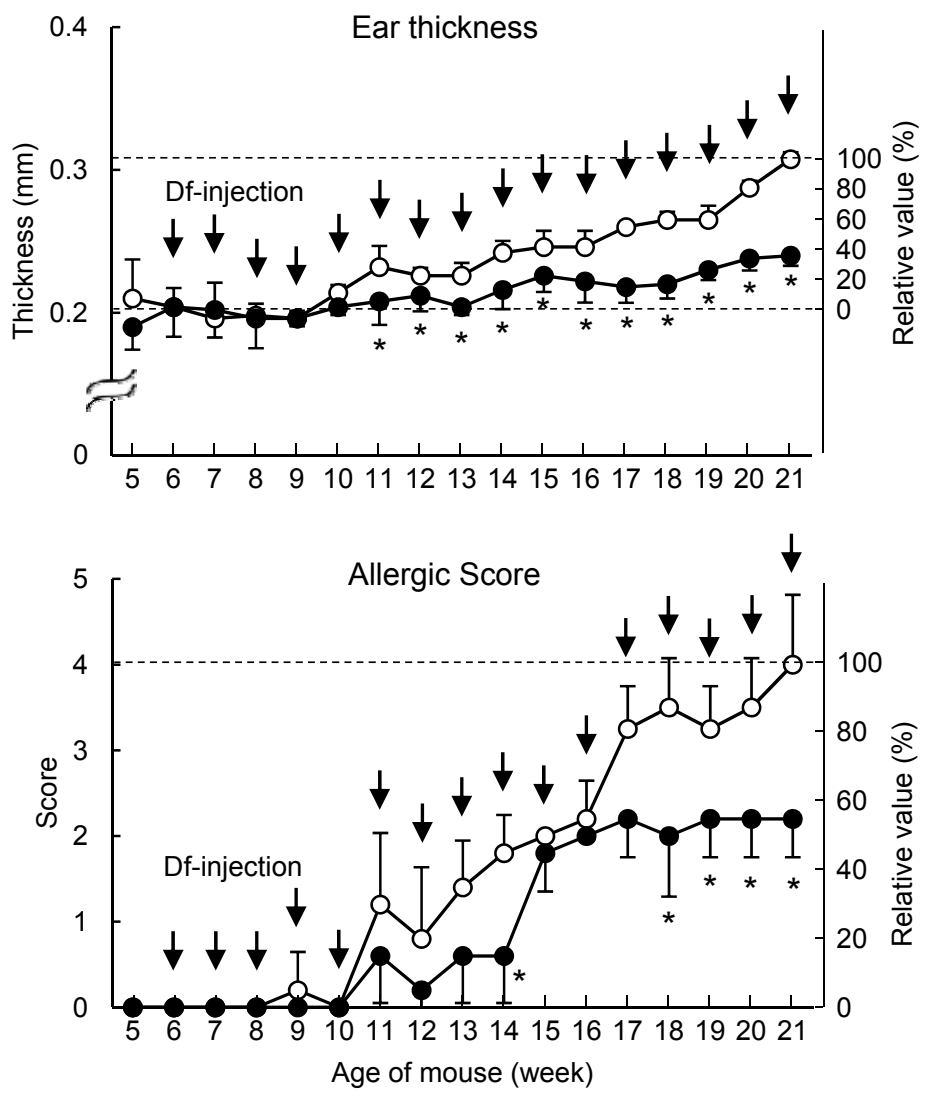

Figure 2. Ear thickness and allergic score in NC/Nga mice fed the date palm-free (the blank circle) or date palm tree fruit extract-added (the filled circle) diet. Ear thickness and allergic score were assessed weekly. Data are presented as the mean $\pm \operatorname{SD}(n=4$ for date palm-free diet and $n=5$ for date palm tree fruit extract-added diet). ${ }^{*} P<0.05$.

Figure 2. Karasawa \& Otani 

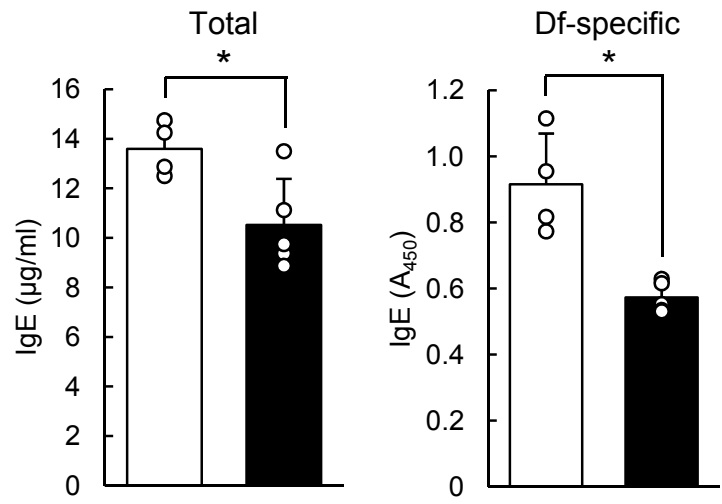

Figure 3. Serum levels of total and Df-specific IgE in NC/Nga mice fed the date palm-free (the blank column) or date palm tree fruit extract-added (the filled column) diet. Data are presented as the mean $\pm S D(n=4$ for date palm-free diet and $n=5$ for date palm tree fruit extract-added diet). ${ }^{*} P<0.05$.

Figure 3. Karasawa \& Otani 

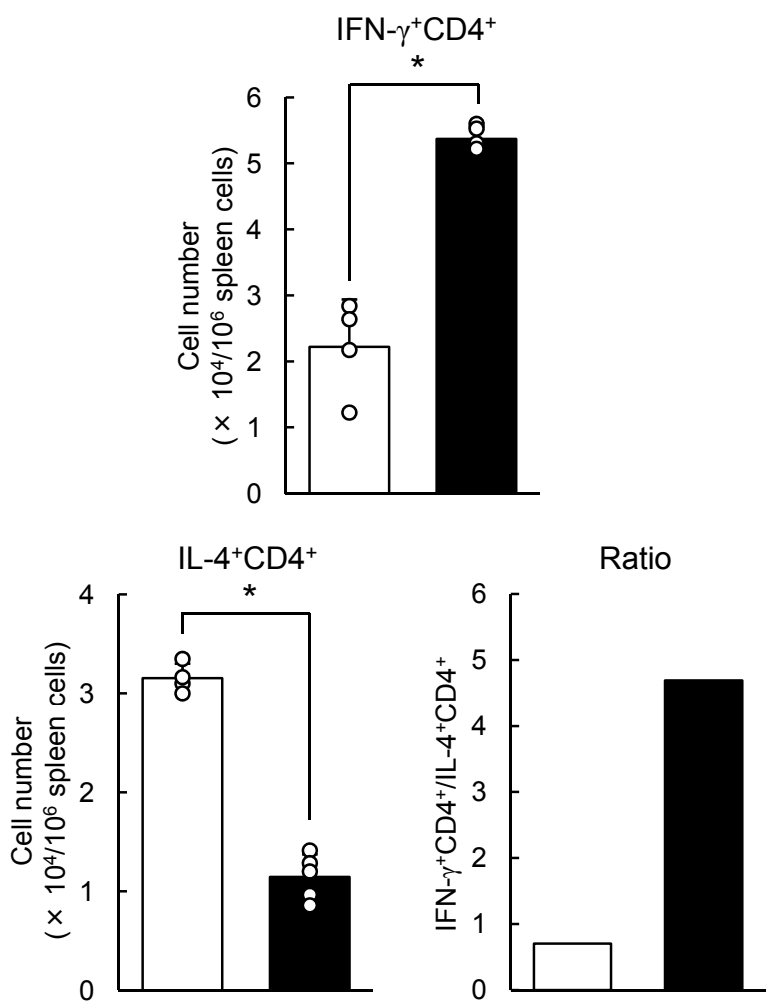

Figure 4. Numbers of spleen IFN $-\gamma^{+} \mathrm{CD} 4^{+}$and IL- $4^{+} \mathrm{CD} 4^{+}$cells in $\mathrm{NC} / \mathrm{Nga}$ mice fed the date palm-free (the blank column) or date palm tree fruit extract-added (the filled column) diet. Data are presented as the mean \pm SD $(n=4$ for date palmfree diet and $n=5$ for date palm tree fruit extract-added diet). ${ }^{*} P<0.05$.

Figure 4. Karasawa \& Otani 


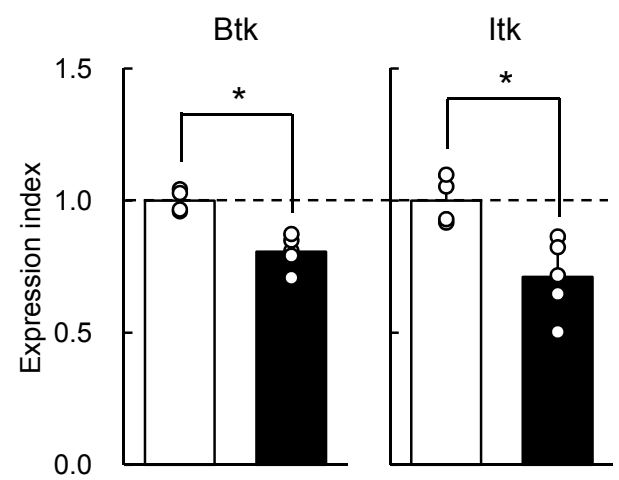

Figure 5. Relative Btk and Itk mRNA expression in spleen cells of NC/Nga mice fed the date palm-free (the blank column) or date palm tree fruit extract-added (the filled column) diet. Data are presented as the mean $\pm \mathrm{SD}$ ( $n=4$ for date palm-free diet and $n=5$ for date palm tree fruit extract-added diet). ${ }^{*} P<0.05$.

Figure 5. Karasawa \& Otani 